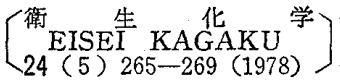

亜鉛カラム法を用いた水中の ppb レベルひ素の原子吸光分析 ${ }^{11}$

深町和美, 德永隆司

福岡県衛生公害センター2)

\title{
Determination of ppb Level of Arsenic in Water by Atomic Absorption Spectrometry using Zinc Column Method ${ }^{13}$
}

\author{
KAZUMI F UKAMACHI and TAKASHI TOKUNAGA \\ Fukuska Environmental Research Center ${ }^{2}$
}

(Received June 15, 1978)

\begin{abstract}
An improved determination system for arsenic was developed by using the apparatus of the hydride generator. The optimum concentration of reducing agents was $4-8 \mathrm{~N}$ hydrochloric acid, $0.1-$ $0.5 \%$ potassium iodide, and $0.015-0.3 \%$ stannous chloride. Evolution of arsine was quantitative in the range of $40-75^{\circ}$ of the zinc column. Sensitivity of this method for $1 \%$ absorption was evaluated to be $0.8 \mathrm{ppb}$ of arsenic and a calibration curve obtained was linear up to $2.0 \mu \mathrm{g}$ of As/50 ml. Coefficients of variation in the determination of 0.6 and $1.5 \mu \mathrm{g}$ of $\mathrm{As} / 50 \mathrm{ml}$ were $3.9 \%$ and $2.35 \%$, respectively, in the runs. The recovery of arsenic added to hot-spring, river, and sea water was $93-100 \%$, with a relative standard deviation of $2.35 \%$. Presence of most metal ions in the sample did not interfere in the determination of arsenic by this method, while selenium (IV), even at concentrations as low as an amount equal to arsenic, interfered in the determination of arsenic.
\end{abstract}

Keywords_-arsenic ; arsine ; atomic absorption spectrometry; zinc column method; determination of As-ppb level

緒言

ひ素に対する感度のよい分析線が $200 \mathrm{~nm}$ 以下にある ため，大気，フレームなどにその共鳴線の吸収が大であ り，空気ーア七チレンフレームを用いる原子吸光法では 微量ひ素の湘定は困難である。このため, 種々の改良を 加えた高感度分析法が報告されている。

そのらちで，ひ素を発生期の水素で還元して得られる アルシンをアルゴンー水素フレームに尊入して，ひ素を 分析するアルシン一原子吸光法があるが，この方法には
（1）アルシン発生びんを用いる Holak らの方法3)や その改良法") 及び（2）亚鉛カラムを用いる菅野らの方 法5)などが報告されている。著者らは，これらを追試し た結果（1）の方法は，かなりの高感度であるが，還元 フラスコ中の試料液に還元剤を投入して，ひ化水素を発 生させる際に若干ひ化水素のもれがあり，そのため精度 に問題があった。また，（2）の方法は試料液の注入方 法によって反応カラムの温度の変動が大きく、このため 精度及び感度が変化するなどの欠点が認められた。

1）日本化学会, 日本分析化学会, 中国四国・九州支部合同大会で発表, 松山, 1976年10月.

2) Location : Dazaifu-machi, Chikushi-gun, Fukuoka (福岡滦筑紫郡太莘府町大字向佐野).

3) W. Holak, Anal. Chem., 41, 1712 (1969).

4) a) D.C. Manning, Atomic Absorption Newsletter, 10，123(1971)；b) 镰田俊彦，奥田久德，熊丸尚 宏，山本勇笓，衛生化学，19，314（1973）；c) 江波戸舉秀，天川映子，山野辺秀夫，鈴木助治，戸谷敕也， 食衛誌, 15，469 (1974)；d) J. Aggett, A.C. Aspell, Analyst, 101, 341 (1976).

5）黑川道子, 金子幹宏, 西山信一, 福井昭三, 菅野三郎, 衛生化学, 21, 77 (1975). 
一方, 最近, 化学炎を用いない無炎原子吸光法の研究 が盛んであり，ひ素をはじめ，種々の元素に対して高感 度分析法が 多数報告されている、6) この方法は，高感度 ではあるが分析操作に熟練を必要とし，さらに共存イ才 ン及び塩なぞの妨害も多く，精度にも難点がある。ま た，多数の検体觉短時間内に分析する場合には適してい ない。

著者らは，亜鉛カラム法により，微量ひ素を高精度で 分析することを目的として，两鉛カラムの反応器を考案 自作しここれを用いたアルシンー原子吸光法の条件を種 々検討した. その結果, 精度, 感度, 穾際試料への適用 などに満足する結果を得たので報告する。

\section{実 験 の 部}

1. 装置原子吸光装置は島津製作所政ダブルビー ムデジタル原子吸光光度計 AA-650型を使用し, 光源に は浜松テレビ製ひ素ホロカソードランプを用いた。バー ナーは $10 \mathrm{~cm}$ スリットバーナーを用い，アルゴンー水菜 フレームを使用した。

アルシン発生装置は Fig. 1 の上うな反応カラム（20 $\times 200 \mathrm{~mm}$ のガラス製カラム)を用い，Fig. 1 のように 連結して使用した。

2. 試薬素 (III) 標集溶液 $(100 \mu \mathrm{g} \mathrm{As} / \mathrm{ml})$ は 三酸化ひ素 $\left(\mathrm{As}_{2} \mathrm{O}_{3}\right) 0.132 \mathrm{~g}$ を $5 \mathrm{~N}$ 水酸化ナトリウム溶 液 $5.0 \mathrm{ml}$ に溶かし, 純水 $400 \mathrm{ml}$ を加立, 硫酸 $(1+9)$ で中和したのち，硫酸 $(1+9) 10 \mathrm{ml}$ を加光，純水で $1000 \mathrm{ml}$ とした.

塩酸は半井化学製のひ素分析用塩酸(30\%)を用いた。

塩化第一スズ溶液 $(15 \mathrm{w} / \mathrm{v} \%)$ は和光純薬製有害金属 分析用塩化第一スズ $\left(\mathrm{SnCl}_{2} \cdot 2 \mathrm{H}_{2} \mathrm{O}\right) 17.8 \mathrm{~g}$ を塩酸 $100 \mathrm{ml}$ に溶解したものを用いた。

ヨウ化カリウム溶液 $(25 \mathrm{w} / \mathrm{v} \%$ は はヨウ化カリウム 25

$\mathrm{g}$ を純水 $100 \mathrm{ml}$ に溶解して調整した。

その他の試薬は市販特級品をとのまま使用した。

3. 定量操作 ひ素 $2.0 \mu \mathrm{g}$ 以下を含检水を $50 \mathrm{ml}$ メスフラスコにとり，塩酸 $21.3 \mathrm{ml}$, ヨウ化カリウム溶 液及び 塩化第一スズ溶液を各々 $1.0 \mathrm{ml}$ 加光, 純水で $50.0 \mathrm{ml}$ とし，原子吸光分析用試料に供する。 Fig. 1 の反応カラムの四方コックをby-passにしてこの試料液 $2.0 \mathrm{ml}$ を注射器を用いて注入する。発生するアルシン を直ちに四方コックを sweep にして，アルゴン気流に よりアルゴンー水素フレームに導入し，ひ素の吸光度を 測定する．測定後は四方コックをby-passにしたのち， 三方コックを開いて廃液をすてる．別に，ひ素を含まな

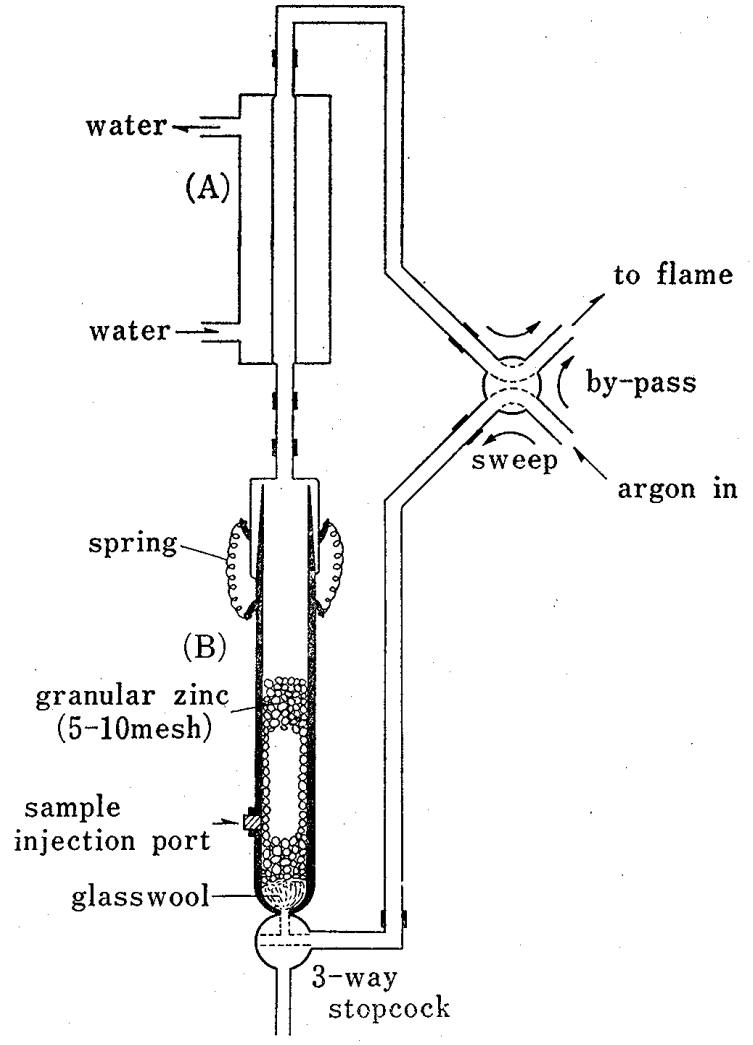

Fig. 1. Diagram of Apparatus Used for Arsine Generation

(A) : condenser

(B) : arsine generator.

い試薬ブランクについて同様に吸光度を測定し，この吸 光度の差から検体中のひ素量を求める. 原子吸光の測定 条件は次のとおりである。分析線波長：1937 ̊,スリッ

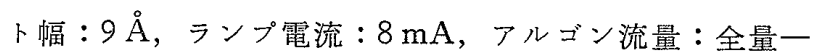
$91 / \mathrm{min}\left(1.5 \mathrm{~kg} / \mathrm{cm}^{2}\right)$, キャリヤー流量一 $31 / \mathrm{min}$, バー ナ一高さ: $1.0 \mathrm{~mm}$, 水素流量: $71 / \mathrm{min}\left(0.4 \mathrm{~kg} / \mathrm{cm}^{2}\right)$.

\section{結棵及び考察}

\section{1. アルシン発生条件}

実験の部 3. の操作に従ってアルシンを発生させる際 の酸濃度, 還元剤 ( 度及び反忘カラム温度などの影響を検討した。

酸濃度 ヨウ化カリウム濃度 $0.5 \%$ 及び塩化第一ス ズ濃度 $0.3 \%$ 共存下に执いて, 塩酸濃度を $0.5-8.0 \mathrm{~N}$ の 範团で变化させた場合の吸光度の変化を調べた．Fig．2 に示すように，4-8 N の範团に叔いて一定吸光度が得ら れた。

なお゙，塩酸の代りに硫酸を用いた場合には，吸光度が 塩酸の場合の半分に減少し，こ玌は鎌田ら ${ }^{4 b)}$ の結果と 異なっている。

6）安田諴二, 垣山仁夫, 分析化学, 23，620（1974）；鎌田俊彦, 熊丸尚宏, 山本勇䉕, ibid., 24, 89 (1975). 


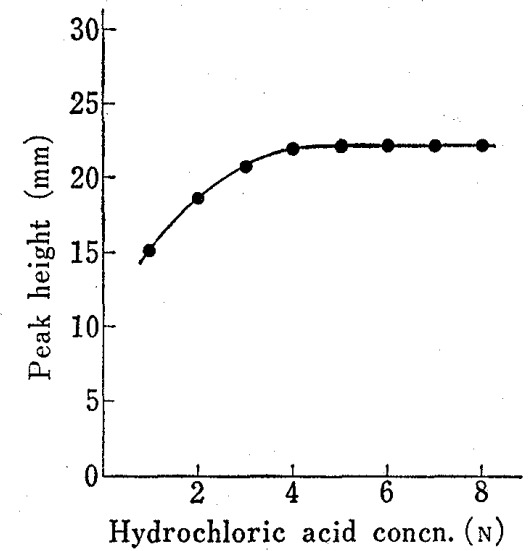

Fig. 2. Effect of Acidity on the Reduction of Arsenic

Arsenic : $1.0 \mu \mathrm{g} / 50 \mathrm{ml} ; \mathrm{KI}: 0.5 \%: \mathrm{SnCl}_{2}: 0.3 \%$.

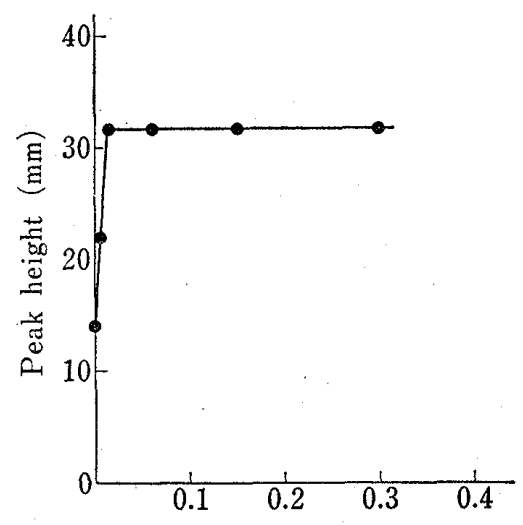

Stannous chloride concn. (\%)

Fig. 3. Effect of Stannous Chloride Concentration on the Reduction of Arsenic

Arsenic : $1.5 \mu \mathrm{g} / 50 \mathrm{ml} ; \mathrm{KI}: 0.5 \% ; \mathrm{HCl}: 5 \mathrm{~N}$.

ヨウ化カリウム濃度及び塩化第一スズ濃度アルシ ン発生に際して，還元剤であるヨウ化カリウム及び塩化 第一スズの添加がアルシンの発生を助けることが知られ ている.そこで，ヨウ化カリウム濃度及び塩化第一スズ 濃度と吸光度との関係をヨウ化カリウム濃度 0-0.5\%, 塩化第一スズ濃度 0一 $0.3 \%$ 範围でそれぞれ検討した。 その結果は Fig. 3，4 亿示す. Fig. 4 から明らかなよ うにヨウ化カリウムの場合，その添加効果は小さいが 0.1 -0.5\%の範囲で，また，塩化第一スズの場合 (Fig. 3） $0.015-0.3 \%$ の範团で，それぞれ一定の吸光度が得 られた。上述のようにヨウ化カリウムの添加効果は小さ いが，共存イオンの妨害はヨウ化カリウムを添加した方 が小さい傾向にあった。

反応カラム温度 水素発生の反応条件がアルシン発 生率に関係すると考光られるので，その反応条件の一つ である温度の影響を反応カラム温度と吸光度との関係で

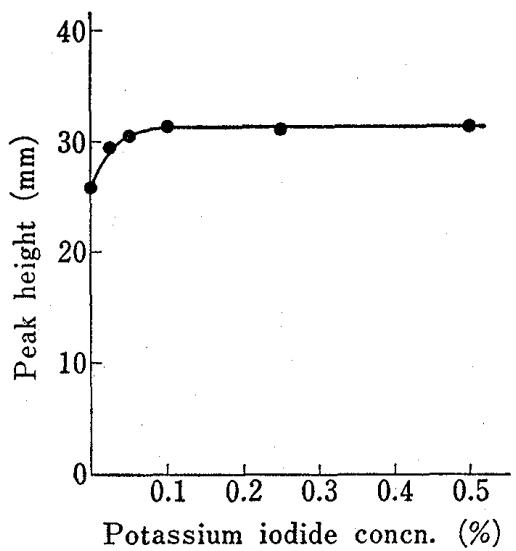

Fig. 4. Effect of Potassium Iodide Concentration on the Reduction of Arsenic

Arsenic : $1.5 \mu \mathrm{g} / 50 \mathrm{ml} ; \mathrm{SnCl}_{2}: 0.3 \% ; \mathrm{HCl}: 5 \mathrm{~N}$.

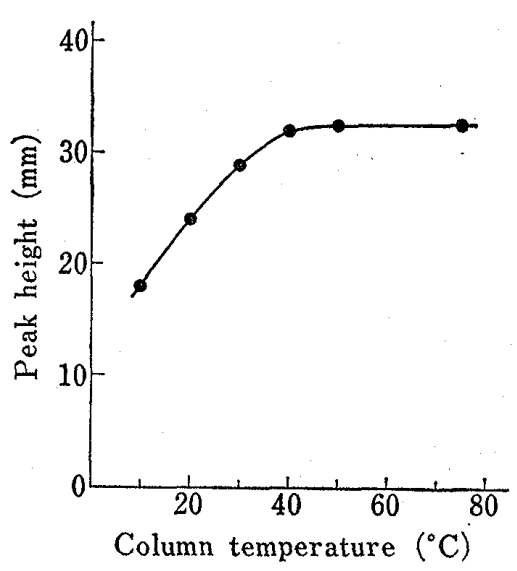

Fig. 5. Effect of Temperature of Zinc-column Arsine Generator on the Reduction of Arsenic

Arsenic : $1.5 \mu \mathrm{g} / 50 \mathrm{ml} ; \mathrm{KI}: 0.5 \%: \mathrm{SnCl}_{2}: 0.3 \% ; \mathrm{HCl}: 5_{\mathrm{N}}$.

検討した. 反応カラム温度を $10-75^{\circ}$ の範囲で変化させ た場合の吸光度の变化を Fig. 5 亿示す. Fig. 5 から明

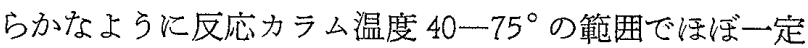
の吸光度値が得られた。

な扮，反応カラムに酸性試料液を注入すると反応熱伅 よって $40^{\circ}$ 以上のカラム温度が得られるので，本報では 特別に反応カラム温度堂制御する必要はなかった。

一方，菅野ら5)の反応カラム方式では，絶えずカラム 内安キャリヤーガスが流れているため，試料液注入時間 の間隔によってカラム温度の变化が大きく，一定温度が 得難い傾向にあった。そのことが試料液注入方法によっ て測定值にばらつきが生じる原因の一つであると考えら れる。

\section{2. 検量線}

以上の条件の検討結果から標準操作を実験の部 3.の 


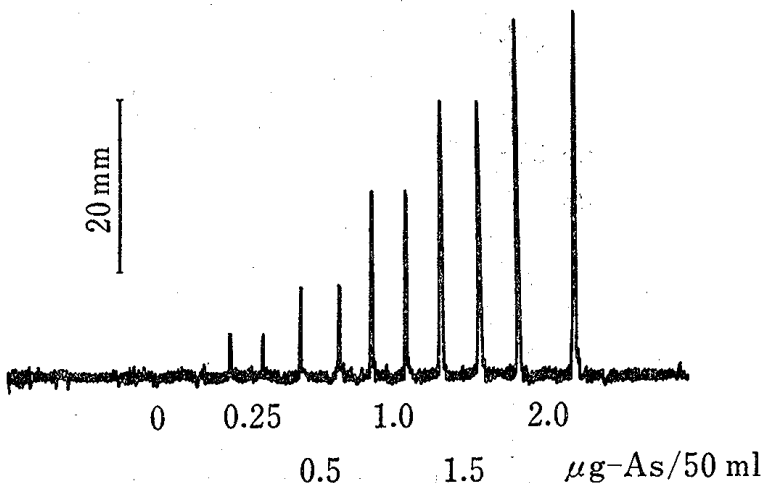

Fig. 6. Absorption Signal vs. Concentration of Arsenic

$\mathrm{KI}: 0.5 \% ; \mathrm{SnCl}_{2}: 03 \% ; \mathrm{HCl}: 5 \mathrm{~N}$.

ように定めた。標準操作に従って, 検量線を作成した結 果，Fig. 6 に示すようにひ素 $2.0 \mu \mathrm{g}$ 以下で原点を通る 良好な直線関係が得られた。

本法の感度は $1 \%$ 吸収で示すと $0.1 \mu \mathrm{g} \mathrm{As} / 50 \mathrm{ml}$ で西 った. 分析精度を $0.6 \mu \mathrm{g} \mathrm{As} / 50 \mathrm{ml}$ 及び $1.5 \mu \mathrm{g} \mathrm{As} / 50 \mathrm{ml}$ の試料溶液について，10回の繰返し試験を行なって求め たところ，相対標準偏差はそれぞれ 3.9\%及び 2.35\%て あった。

$0.2 \mu \mathrm{g} \mathrm{As} / 50 \mathrm{ml}$ 溶液の反応カラムへの注入量を 1.0 $-5.0 \mathrm{ml}$ の範囲で変化させた場合の注入量と吸光度と の関係を調べた。そ結果, この注入量範囲では, 原点 を通る直線関係が得られるので，試料注入量は 1.0-5.0 $\mathrm{ml}$ の範囲で変化させることが可能である.

\section{3. 共存イオンの影響}

ひ素を $1.5 \mu \mathrm{g}$ 含屯溶液に河川水, 海水及び種々の排 水中に含まれると思われる陽イオンあるいは陰イオンの 塩を添加し，定量操作に従ってその影響を検討した。 そ の結果を Table I に示す。大部分の陽イオンはひ素に 対して $10^{4}$ 倍程度共存してもほとんど影響しない。しか し，セレン（IV）の影響は大きい。

\section{4. 実際試料の分析結果及び添加回収率}

$T_{A B L E}$ I. Effect of Diverse Ions

As : $1.5 \mu \mathrm{g}$

\begin{tabular}{|c|c|c|}
\hline Diverse ions & $\begin{array}{l}\text { Added amount } \\
(\mathrm{mg})\end{array}$ & $\begin{array}{l}\text { Error } \\
(\%)\end{array}$ \\
\hline $\mathrm{NaCl}$ & 1500 & 0.0 \\
\hline $\mathrm{K}^{+}$ & 15 & +3.2 \\
\hline $\mathrm{Mn}$ (VII) & 15 & -3.2 \\
\hline $\mathrm{Fe}^{2+}$ & 15 & -3.2 \\
\hline $\mathrm{Co}^{2+}$ & 1 & 0.0 \\
\hline $\mathrm{Mo}(\mathrm{VI})$ & 15 & -3.2 \\
\hline $\mathrm{Ag}^{+}$ & 1 & 0.0 \\
\hline $\mathrm{Cd}^{2+4}$ & 1 & +2.7 \\
\hline $\mathrm{Sb}^{3+}$ & 7.5 & +0.3 \\
\hline $\mathrm{Hg}^{2+}$ & 7.5 & 0.0 \\
\hline $\mathrm{Pb}^{2+}$ & 15 & -0.9 \\
\hline $\mathrm{NO}_{2}^{-}$ & 15 & -3.5 \\
\hline $\mathrm{NO}_{3}^{-}$ & 15 & -0.9 \\
\hline $\mathrm{PO}_{4}^{3-}$ & 15 & -2.3 \\
\hline $\mathrm{S}^{2--}$ & 0.5 & 0.0 \\
\hline $\mathrm{SO}_{4}^{2-}$ & 75 & 0.0 \\
\hline $\mathrm{Se}(\mathrm{IV})$ & $1 \mu \mathrm{g}$ & +1.6 \\
\hline
\end{tabular}

Followings are tolerable $15 \mu \mathrm{g}: \mathrm{Cu}^{2+}, \mathrm{Fe}^{3+}, \mathrm{Ni}^{2+}, \mathrm{Zn}^{2+}$, $\mathrm{Cr}(\mathrm{VI}), \mathrm{Cr}^{3+}, \mathrm{Al}^{3+}, \mathrm{Mn}^{2+}, \mathrm{Ca}^{2+}, \mathrm{Mg}^{2+}, \mathrm{CO}_{3}^{3-}, \mathrm{ClO}_{4}^{-}$.

都市地区を流孔る河川の河川水とその河口海域の海水 ならびに温泉水について，本法による分析值と標準添加 法による回収突験の結果を Table II に示ず. 本報で用 いた試料溶液に $1.5 \mu \mathrm{g}$ のひ素をそれぞれ添加して得た 標準添加法の回収率の範围は93-100\%であり，その時

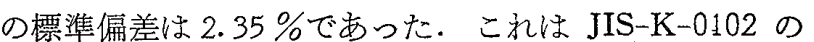
DDTC-Ag 法に比べて回収率の変動は小さい。

$$
\text { 結語 }
$$

アルシン発生用亜鉛反応カラムを考案自作し，このカ ラムを用いたアルシンー原子吸光法による微量ひ素の高 精度分析法を確立した。

その分析条件は, 酸濃度： $5 \mathrm{~N}$ 塩酸, ヨウ化カリウム

TABLE II. Analytical Results of Water and Recovery of Added Arsenic

\begin{tabular}{|c|c|c|c|c|c|}
\hline Sample & & $\begin{array}{l}\text { As found } \\
(\mu \mathrm{g} / 50 \mathrm{ml})\end{array}$ & $\begin{array}{l}\text { As added } \\
(\mu \mathrm{g})\end{array}$ & $\begin{array}{l}\text { As found } \\
(\mu \mathrm{g} / 50 \mathrm{ml})\end{array}$ & $\begin{array}{c}\text { Recovery } \\
(\%)\end{array}$ \\
\hline River water & $\begin{array}{l}1 \\
2 \\
3\end{array}$ & $\begin{array}{l}0.00 \\
0.00 \\
0.00\end{array}$ & $\begin{array}{l}1.50 \\
1.50 \\
1.50\end{array}$ & $\begin{array}{l}1.45 \\
1.49 \\
1.46\end{array}$ & $\begin{array}{l}96.7 \\
99.3 \\
97.3\end{array}$ \\
\hline Sea water & $\begin{array}{l}1 \\
2 \\
3\end{array}$ & $\begin{array}{l}0.00 \\
0.00 \\
0.15\end{array}$ & $\begin{array}{l}1.50 \\
1.50 \\
1.50\end{array}$ & $\begin{array}{l}1.45 \\
1.43 \\
1.54\end{array}$ & $\begin{array}{l}96.7 \\
95.3 \\
92.7\end{array}$ \\
\hline Hot-spring water & $\begin{array}{l}1 \\
2 \\
3\end{array}$ & $\begin{array}{l}0.20 \\
1.92 \\
0.00\end{array}$ & $\begin{array}{l}1.50 \\
1.50 \\
1.50\end{array}$ & $\begin{array}{l}1.62 \\
3.36 \\
1.49\end{array}$ & $\begin{array}{l}94.7 \\
96.0 \\
99.3\end{array}$ \\
\hline
\end{tabular}


濃度 : $0.5 \%$, 塩化第一スズ濃度 : $0.3 \%$, 反応力ラム温 度：40以上(これは特別に外部から加熱する必要はな い), 試料液のカラム注入量：1.0-5.0 ml（最適量は $2.0 \mathrm{ml}$ 程度) などである.

分析感度は $1 \%$ 吸収で表わすと0.8 $\mathrm{ng} \mathrm{As} / \mathrm{ml}(5.0 \mathrm{ml}$ 注入の場合）であり，精度は相対標準偏差で示すと 0.6 $\mu \mathrm{g} / 50 \mathrm{ml}$ 及び $1.5 \mu \mathrm{g} / 50 \mathrm{ml}$ 溶液に対して；それぞれ $3.9 \%$ 及び $2.35 \%$ であった。

河川水, 海水及び温泉水に対し，本法を適用して得た
ひ素の分析値及び標準添加法の回収率などにおいても満 足する結果が得られた。

謝辞有益な御意見及び校閲を賜わった九州大学工 学部工業分析化学教室 石橋信彦教授に愿くお礼申乙上 げます。また，激励をいただいた当衛生公害センタ一 猿田南海雄所長, 高橋克已副所長, 木藤寿正部長並びに 森本甾宏課長に感謝します。 